symbolism at the University of Michigan. In the second, 325,000 dollars were appropriated in 1950 for the studies initiated at Cornell University, with field headquarters at Bangkok, into the effects of technological and economic change on the peoples of South-East Asia, the effects of the United States and the United Nations programmes on the political structures and ideologies in the area, and the status of Chinese and Indian minority groups there. The Institute of Islamic Studies at MeGill University, Montreal, has received 214,800 dollars for a five-year period, and grants totalling 194,000 dollars have been made in support of the programme of American studies, launched jointly in 1950 by the University of Tokyo and Stanford University.

The grants, totalling nearly 1.5 million dollars in 1950 and more than 1.6 million dollars in 1951, made through the Division of Humanities, were, Mr. Barnard points out, inspired by the belief that in this field, as in the social sciences, the emphasis is no longer on knowledge but rather on the contribution that may be made to the processes by which our attitudes, beliefs and judgments of value are developed, made more coherent and integrated into a harmonious pattern. If these processes are to be kept healthy in a free society, Mr. Barnard suggests that it is important, first, that the society have creative effort which is really producing new ideas and putting them into understandable forms. Criticism is also essential, to keep creative workers operating on constructive lines; lastly, what $\mathrm{Mr}$. Earnard terms-for want of a more descriptive word - experience is also needed. These are among the reasons which lead the Foundation to foster research and writing in modern history--for example, dramatic writing - and to promote the freedom of the Press. Of the 3,149 applications for aid declined in 1951, 973 were for fellowships, scholarships and travel and training grants, and 618 for support of scientific research projects and teaching programmes.

\section{UNITED STATES PULP AND PAPER INDUSTRIES}

T $\mathrm{N}$ a world where raw materials of all sorts are at I a premium, a publication, No. 7 of the Royal School of Forestry, Stockholm, entitled "U.S. Pulp and Paper Industry with Special Reference to its Supply of Raw Material"*, is of particular interest. The consumption in the United States of paper and paperboard prior to the Second World War amounted to about 50 per cent of the total world consumption, and the corresponding figure has now risen to about 70 per cent, owing to the rise in the United States domestic consumption; this latter rose from 15.2 million metric tons in 1940 to 22.5 million metric tons in 1949, the equivalent of an increase from $114 \mathrm{kgm}$. to $153 \mathrm{kgm}$. per head of the population. In Sweden, where the consumption per head is probably the largest in Europe, the corresponding consumption for the same year was $80 \mathrm{kgm}$.

The question is, how are the United States to cover their long-term needs in the way of paper and board, and fundamentally this is a question of

* Kungl. Skogshögskolans Skrifter 7 : Förenta staternas massa- och pappers-industri med särskild Länsyn till des rávaruförsörjning (U.S. Raw Material). Av. Th. Streyffert. Pp. 85. (Experimentalfaltet, K.S., 1952.) raw-material resources. How much can they obtain from their own forests? The balance must be imported. In 1949, 35 per cent of the paper and board consumption was covered by imports in the form of paper, wood pulp or pulp wood. The consumption of pulp wood rose from 14.5 million cubic metres in 1925 to $17 \cdot 8$ million in 1935 and $24 \cdot 2$ million in 1949 . In the last-named year the United States imported $4 \cdot 3$ million tons of paper (the bulk of it newsprint), 1.6 million tons of wood pulp and 4.3 million cubic metres of pulp wood. All the pulp wood, the greater bulk of the newsprint, and three-quarters of the wood pulp came from Canada and Newfoundland, and the balance from Scandinavia and Finland.

At the same time the forests of the United States have been yielding a progressively increasing volume of raw material. Pulp wood has increased from $12 \cdot 7$ to $44 \cdot 7$ million cubic metres between 1925 and 1949. This is partly due to the amount coming from new forests in the southern States and Pacific northwest. More intensive valuations of the volume of timber in the coniferous forests are now available, and it is apparent that over-cutting, that is, exceeding the annual increments put on, is taking place in the coniferous forests. In the hardwood forests, for long neglected, the annual increment considerably exceeds the volume felled. It is in this latter type of forest that the United States will have to look in the future for some of their requirements. In how far the annually increasing demands will be met by Canada, Scandinavia and other European countries and so forth is problematical, for Europe requires a far larger amount of these materials than are at present available to her.

\section{PROXIMITY OF GENES CONTROLLING THE FERMENTATION OF SIMILAR CARBOHYDRATES IN SACCHAROMYCES}

\section{By Prof. CARL C. LINDEGREN and GERTRUDE LINDEGREN}

Biological Research Laboratory, Southern Illinois University, Carbondale, Illinois

GOUR different genes in Saccharomyces controlling the hydrolysis of alpha-glucosidic saccharides are on the same chromosome. The genes $M A, M Z$ and $M G$ controlling the hydrolyses of maltose, melezitose and alpha-methyl glucoside are in one linkage group ${ }^{1}$ : (1) $M A$ and $M Z$ were shown to be linked by frequency of recombination; (2) $M A$ and $M G$, which usually recombine freely, were shown to be on the same chromosome by the spontaneous appearance of a crossing-over suppressor in one family. The observations presented here show that $S U$ (which controls the fermentation of sucrose and raffinose by producing a beta-fructo furanosidase) is a member of the same linkage group. Saccharomyces chromosomes are extraordinarily long genetically, and in most experiments $M A, M G$ and $S U$ recombine independently. Linkage between $M G$ and $S U$ was revealed by the suppression of crossing-over between them, presumably due to the spontaneous occurrence of an inversion. The pedigree described below overlaps one described 